\title{
Secrecy versus transparency in the US national security surveillance state
}

\author{
Paweł Laidler
}

\section{Introduction}

In 2013, Edward Snowden, the former National Security Agency (NSA) contractor, copied classified documents that revealed the scope of US government surveillance. The leaked documents referred to secret programs that enabled the collection of metadata on foreign and American citizens, and to the interception of domestic internet communications leading to the creation of an enormous database by government surveillance agencies with access to personal communications, including emails, social network entries, audio and video chats, visited websites, and medical and financial records (Olmsted 2018; Greenwald 2014; Gurnow 2014). Snowden's revelations ignited social and political discussion concerning the scope of government surveillance powers, as well as the impact of the secret NSA programs on the privacy of American citizens and on various potential violations of the constitution by the authorities (Goldfarb 2015; Lyon 2015; Kitrosser 2015). The substance of the leaked documents ignited an academic debate on the functioning of the US foreign and domestic surveillance system and its impact on the state of democracy and the rule of law.

Research has been conducted with regard to both national security and domestic surveillance in the United States, with a focus on the powers of institutions responsible for conducting or controlling surveillance procedures, as well as on the conflict this has caused between freedom and security (Farrell and Newman 2019; Johnson 2018; Keller 2017; Goldfarb 2015; Lester 2015; Angwin 2014) and between secrecy and transparency (Graham 2017; Frost 2017; Kitrosser 2015; Arnold 2014). It is no surprise to learn that the NSA was the most studied institution (Hayden 2018; Edgar 2017), but important analysis has also been done with regard to the surveillance activities of the Central Intelligence Agency (CIA) (Johnson 2018; Prados 2014) and the Federal Bureau of Investigation (FBI) (McCabe 2019). Studies focusing on concrete surveillance institutions have had at least one thing in common: a broader reference to the role of the executive branch of government in building, 
preserving, and defending a complex system of secret surveillance aimed at providing national security.

Unlike the case of post-9/11 legislation and executive action, when the main theme of the public debate focused on the clash between freedom and security (Herman 2011; Posner and Vermeule 2006; Davis and Silver 2003), the post-Snowden era has been marked by a more frequent reference to the clash between two other important features of a surveillance state: secrecy and transparency. The debate has raised questions concerning the excessiveness of the US secrecy regime with respect to surveillance policies, appealing to the necessity of imposing broader transparency measures which would restore democracy and enable a proper oversight of the government's actions (Edgar 2017). Transparency has become the most demanded value, treated by many as a remedy for the overwhelming system of excessive secrecy and overclassification (Goldfarb 2015; Kitrosser 2015).

The problem the chapter addresses concerns the struggle between secrecy and transparency rooted in the institutional and systemic mechanisms of the separation of powers and the checks and balances system in the United States. I argue that in the area of national security surveillance, the adherence of the executive toward secrecy outweighs transparency as promoted by Congress and defended by the judicial branch. It seems that - not despite but because of the separation of powers doctrine - there is more secrecy rather than transparency in US national security surveillance, which may lead to an argument about the illusion of transparency within the national security framework. The illusion, understood as a difference between the reality and the perception of the reality, in this context means that although the government has undertaken several legal and political measures to achieve the socially demanded level of transparency, the result has been more a matter of perceived than actual change, due to the engagement of all branches in the defense of secret surveillance. The chapter analyzes the policies of these branches toward the conflict between secrecy and transparency in the area of national security surveillance in the pre- and post-Snowden eras. Due to the fact that congressional legislation, executive action, and judicial interpretation of surveillance measures are intertwined, the empirical analysis is conducted in chronological order, focusing on the most important issues occurring before and after 2013.

For the purpose of the study, surveillance is defined as "the collection of information in order to manage control" (Lyon 2015, 3) with "the intention to protect, understand ... or influence groups or individuals" (Kuntze 2018, 45). Considering government surveillance, it seems obvious that in a democratic state there should be a mutual relationship based on control: the authorities control the society, and the society controls the authorities, although the character of the two types of control is quite different and is conducted with varying intensity. By managing control, the surveilling party influences the lives of surveilled subjects, often justifying it by the need to protect them; however, the scope of this protection is determined by means of surveillance 
and its more (or less) secretive character. The biggest challenge concerns the level of understanding among the subjects of the surveillance relationship, as it often has an impact on the scope of the accountability of the surveillance programs. This can be seen especially in government surveillance, where the society, aware of the authorities' need to impose certain measures of surveillance, is reluctant to approve the culture of secrecy in which the surveillance state is shrouded (Arnold 2014). In what follows, government surveillance shall refer to national security surveillance, that is, US foreign intelligence surveillance and other surveillance activities conducted by the intelligence community, as well as by the institutions involved in such activities (Friedman and Hansen 2012). Although the 2013 leaks revealed the scope of US surveillance of foreigners, including political leaders, and thus affecting transatlantic relations (Cole et al. 2017), the analysis focuses mainly on those aspects of national security surveillance which were directed toward American citizens, raising the problem of constitutionality and governmental accountability.

In discussions of national security surveillance, transparency should be understood as oversight and control of the activities of institutions involved in conducting government surveillance, rather than the full disclosure of information concerning surveillance programs and their outcomes. In order to pursue the politics of national security effectively, the government must be allowed to act in partial secrecy and to select the means necessary to provide the expected level of safety to its citizens (Cain 2015, 41). But the lack of control from oversight institutions may lead to the abuse of power and to violations of the rights and freedoms of individuals, who demand a certain level of transparency from their government. Such a level could be reached, for example, by legislation limiting the scope of national security surveillance, as well as by institutional solutions providing for a system of effective oversight imposed on different levels and in different relations (Eskens et al. 2015, 8). From the perspective of the separation of powers, control over executive actions should be conducted by both Congress and the judiciary, despite the different character of their functioning. It seems that without the people's knowledge of the scale and character of government surveillance, resulting from the effects of this congressional and judicial oversight, there is neither democratic accountability nor the proper functioning of the constitution as a fundamental guarantee of individuals' rights.

The core question about the relation between secrecy and transparency is not new to surveillance studies and has been examined from various perspectives (Moses and de Koker 2017; Lyon 2014; Ball et al. 2012; Friedman and Hansen 2012; Theoharis 2011; Herman 2011). The methodology of political and legal sciences applied here, based on historical institutionalism and systemic analysis, will focus on the character of the separation of powers doctrine, which evolved along with the growth of the secret surveillance state. The system revealed by Snowden, who uncovered a secret web of programs conducted by the federal executive and uncontrolled by Congress and the 
courts, affected the checks and balances system (Goldfarb 2015; Arnold 2014; Greenwald 2014). Some researchers placed the responsibility for the existence of the secret surveillance state on concrete examples in specific presidential administrations (Graham 2017; Glennon 2015; Theoharis 2011); some tried to find the explanation for the temporary violation of the rights and freedoms of individuals in a state of emergency (Edgar 2017); and others have explained that the executive acted in accordance with the Constitution (Calabresi and Yoo 2012). These research findings confirmed conflicting arguments raised by politicians, journalists, and American citizens, who presented different approaches toward the interpretation of the constitutional powers of the government with respect to its surveillance competences. My argument focuses mainly on the scope of the separation of powers doctrine, which is the key to understanding why the transparency of national security surveillance has been an illusion, rather than a reality.

\section{National security surveillance pre-Snowden}

\section{The Cold War era}

The national security paradigm has always been rooted in the American political system, becoming an indispensable element of the policies of most presidential administrations. It has been systematically used since the late 1940s, usually applied by the executive with regard to foreign policy (Theoharis 2011, 133-5). The separation of powers was not in the spotlight of early Cold War national security legislation, but Congress was aware that the expansion of executive powers should be somehow controlled by other government branches. The National Security Act of 1947 placed theoretical limitations on the functioning of the intelligence community, by requiring the president to keep Congress "fully and currently informed of the intelligence activities of the United States, including any significant anticipated intelligence activity" (National Security Act 1947). The law confirmed congressional oversight over intelligence activities, but it was obvious that the scope of control and transparency would depend on a president's will.

Five years later, President Harry Truman issued a top-secret directive establishing the NSA, responsible for monitoring communications out of the United States (Glennon 2015, 12-13). In order to achieve national security goals, the government operated several secret surveillance programs aimed at both foreign and national subjects. Institutionally, all three major agencies, the NSA, the CIA, and the FBI, were involved in the process of protecting national security during the Cold War era, and their activities were held far from public scrutiny due to the imposition of a broad secrecy system (Edgar 2017). Surveillance measures quickly became an effective tool of government agencies' control of the communications and activities of US persons involved in "subversive activities" (Dudziak 2000). At the same time, the NSA 
was involved not only in counterintelligence but strictly collaborated with both the CIA and the FBI in sharing information about foreign and domestic threats to national security (Keller 2017).

The truth about several secret surveillance programs was revealed during the investigations conducted by congressional oversight committees established in the mid-1970s: the Pike Committee (House) and the Church Committee (Senate). The investigations focused on the secret and - in many respects - illegal programs conducted by the CIA and NSA, as well as on the FBI's wiretapping of politicians and journalists (Prados 2014). The Church Committee's investigation, followed by a series of reports, not only disclosed the scope of national security surveillance for domestic reasons but also raised concerns about the character of the separation of powers with regard to national security surveillance. The Committee found that "intelligence activities were essentially exempted from the normal system of checks and balances," decreasing the constitutional accountability of the executive, which had an exclusive role in conducting national security policies, including surveillance of US citizens. The report indicated that the executive agencies applied excessive secrecy in their conduct of surveillance programs in order to limit congressional oversight and the knowledge of the people targeted by government due to their political beliefs (Church Committee Report 1976).

As a result, Congress established two stable oversight bodies whose role was to control foreign intelligence and counterintelligence activities and expanded the powers of the justice committees of both houses to oversee the actions of domestic surveillance agencies (Glennon 2015; Solove 2011). Furthermore, in 1978 Congress implemented the Foreign Intelligence Surveillance Act (FISA), introducing higher judicial scrutiny over national security surveillance measures and establishing the Foreign Intelligence Surveillance Court (FISC) to grant warrants for the surveillance of those who were suspected of being foreign agents (Foreign Intelligence Surveillance Act 1978). The means of appointment of FISC judges, as well as the length of their tenure and the necessity to close the court's proceedings to the public, were aimed at producing a system of judicial check on the activities of institutions imposing surveillance, without violating the sensitive character of the cases discussed. On the other hand, the special court had to operate on the basis of information and documents provided solely by the executive, which made its proceedings and decision-making process dependent on the value and relevance of the shared data (Glennon 2015, 45). Theoretically, transparency was weakened by institutional secrecy.

The analysis of the legislative and institutional effects of the committees' investigations proves that Congress did not want to strip the executive of the power to exercise its constitutional goal of providing security to US citizens. The secrecy rule guiding the FISC procedures, and the discretionary power of the executive to control the content of shared information with the judges, served the purposes of national security. None of the congressional acts or 
institutional changes within the government significantly limited the scope of national security surveillance. Furthermore, the Supreme Court confirmedor at least did not neglect - the leading role of the executive in implementing and operating national security policy, even if it resulted in violations of the civil rights of Americans. The reference to the privilege of state secrets in the dispute over the crash of a military plane (United States v. Reynolds 1953), lack of ripeness in a case concerning US Army surveillance of American citizens (Laird v. Tatum 1972), or the limitation of First Amendment rights during the Red Scare era of the early 1950s (Dennis v. United States 1951) may serve as good examples of the strengthening of the government's powers for national security reasons.

\section{The post-9/II era}

The secrecy of national security surveillance was again at the center of US political debate after the terrorist attack of 9/11, when Congress implemented antiterrorist legislation. The USA Patriot Act became the main source of power for the federal institutions responsible for law enforcement and intelligence activities (Smith and Hung 2010). Among various provisions determining the relations between executive agencies, the Act introduced National Security Letters (NSL), issued without judicial control by the FBI, and roving wiretaps focusing on individual persons rather than the devices which they used (USA Patriot Act 2001). Generally, Congress agreed to expand executive powers by delegating vast competences to executive agencies, referring to the times of emergency (Akerman 2006), which allowed the George W. Bush administration to justify its national security policy.

Among several measures undertaken by the administration was a secret program, called Stellar Wind, which became public due to a press leak in 2005 (Fisher 2013, 251-2), as a part of a broader Terrorist Surveillance Program (TSP) implemented in 2002 (Kuntze 2018, 82). Its main purpose was to collect international phone calls and emails of targets suspected of organized terrorism, but in addition to data on foreign nationals the program allowed the NSA to intercept and store metadata from telephone and internet providers, including information about the private communications of US citizens (Edgar 2017, 40). Importantly, Stellar Wind not only lacked the approval of Congress and the judiciary, including the FISC, but it was also based on an internal memorandum created by the Office of Legal Counsel (OLC). The document assumed that presidents-based on unitary executive theory - had almost unlimited power in determining the scope of government surveillance (Posner and Vermeule 2006). The theory claimed that the president, as commander-in-chief, had the power to initiate any surveillance program, because all executive power belonged to the president, especially in times of war and emergency (Goldfarb 2015). Apart from legitimizing Stellar Wind and other initiatives of the TSP, the memo indicated that the lack of 
control by other branches of government was justified by the necessity to keep the programs secret (Lester 2015).

In 2007, the government decided to launch a new national security surveillance program, called PRISM, to monitor the data of the users of the most important internet providers. As a result, in order to provide information necessary to limit the terrorist threat the NSA secretly collected, stored, and analyzed billions of items of data on US citizens (Edgar 2017, 5). In contrast to Stellar Wind, PRISM was based on congressional authorization, Section 702 of the Protect America Act (2007), and the FISA Amendments Act (2008). The legislation permitted the government to intercept communications inside the country connected with foreign suspects of terrorism, but it had to be approved by the FISC, which applied minimization rules in order to protect the rights of American citizens. Still, the reasonable belief standard substituted the former probable cause standard, thus making it easier for the government to obtain FISC approval.

According to Section 702 of the 2007 Act, the government also conducted socalled upstream collection, which focused only on domestic communications by intercepting information from major internet cables and switches in the flow of communications between communication service providers (Edelson 2016, 120). The executive also used the amended Section 215 of the Patriot Act to intercept data from domestic bulk collection of international and domestic telephone records. It guaranteed thousands of numbers analyzed with regard to one seed number, providing for the almost infinite collection of data concerning US persons (USA Patriot Act Additional Reauthorizing Amendments of 2006).

All these programs introduced some level of control over the surveillance activities of the executive. After 2006 especially, Congress and the courts became more actively involved in the process of overseeing national security surveillance measures imposed by the NSA or FBI. Still, national security surveillance, or rather dataveillance (Lyon 2014; van Dijck 2014), was imposed so broadly that there was no way for the oversight institutions to exercise their powers effectively. The collection of the electronic data of foreign and US citizens by government agencies was often conducted without the approval of FISC, or based on a general acceptance of the operation of certain surveillance programs by the court (Glennon 2015). Despite theoretically broader congressional and judicial control of the surveillance measures, there was a lot of criticism that too much information was kept secret, thus leading to potential overuse of executive powers (Herman 2011; Romero and TempleRaston 2007).

Barack Obama's win in 2008 gave hope to his supporters of a change in the national security surveillance system, especially with regard to the scope of powers of the executive, and the level of transparency (Olmsted 2018, 220). As a Senator, Obama had criticized the administration's accumulation of powers for the purpose of the war on terror, but he did not condemn any 
concrete NSA surveillance program (Edgar 2017, 51-52). As a presidential candidate he referred to the greater transparency of the government's surveillance programs (Graham 2017, 180-181). The fact is that as president, Obama modified, and even expanded, some of the surveillance programs initiated by the Bush administration. He decided to continue programs based on Section 215 of the Patriot Act, approved the continuation of PRISM based on Section 702 of FISA, actively used the NSL, and signed the extension of the FISA Amendments Act (Graham 2017; Glennon 2015). It seems as if the main purpose of Obama's administration was to adapt the law to serve the purposes of the politics of surveillance rather than impose a new system of transparency.

\section{National security surveillance post-Snowden}

Soon after the Snowden revelations, President Obama insisted on conducting a broad investigation of NSA surveillance, appointing a Review Group on Intelligence and Communications Technology. It recommended several reforms, from terminating the existing surveillance programs to preserving a limited impact of the NSA on the collection of the data necessary to conduct effective surveillance against potential terrorists (Kitrosser 2015, 338). In early 2014, the White House issued a directive that clearly stated that "the collection of signals intelligence [was] necessary for the United States to advance its national security and foreign policy interests and to protect its citizens and the citizens of its allies and partners from harm" (Presidential Policy Directive 2014, 28). As a confirmation of the differences between the rhetoric and activities of the presidential administration, Obama's government denied access to several requests for information about government actions (Keller 2017, 31).

At the same time, Congress initiated a discussion over legislative reform that would legalize the existing surveillance programs. The Privacy and Civil Liberties Oversight Board (PCLOB) produced a report that concluded that the NSA's program of bulk collection of phone data raised several constitutional issues concerning both the scope of executive powers and potential violations of individuals' freedoms. The report determined certain NSA surveillance programs as illegal and ineffective, thus raising several doubts concerning their continuation (The Report of the PCLOB). With regard to the bulk collection of phone metadata, the Board suggested that the program should be terminated, determining also that the way to intercept the communications stored by telecommunications companies was to obtain the approval of FISC for every individual case of reasonable surveillance (Graham 2017, 197-8).

Finally, in June 2015, the USA Freedom Act (2015) was enacted, thus ending the government surveillance program of bulk collection of metadata. The Act forced the government to obtain FISC warrants in order to conduct 
the collection of data from telecommunications companies for foreign intelligence reasons. For the purpose of preventing previous procedural flaws, judges received expert support from technical and privacy advisers, and their legal interpretations became public. Important change was made with respect to the records collected by telecommunications companies, which stored them instead of the NSA; however, the agency could gain access to these records given FISC approval. The Act also limited the NSA's access to targeted individuals' phone records and the records of the phone numbers associated with them (Graham 2017, 198; Olmsted 2018, 223).

Despite strengthening the checks and balances system with regard to judicial control of government surveillance, and ending the bulk collection of metadata, no serious changes were introduced to the institutional and structural aspects of surveillance programs. Actually, the bulk collection of metadata ended six months after the implementation of the Freedom Act, as the presidential administration asked FISC for a transition period that would allow the analysts to end their work (Edelson 2016, 116). Still, the government did not suggest the creation of any new oversight system, but a strengthening of the existing one with effective control of congressional committees and FISC, and the support of such institutions as PCLOB. Analysis of the legal regulations governing the functioning of the oversight system proves, however, that the scope of control of the surveillance measures depended on the will of the executive, which could easily hide behind national security arguments. And even the publication of annual transparency reports by the NSA did not change the feeling that there was more of a rhetoric of openness rather than real transparency (Alloa and Thoma 2018).

Apart from legislative changes, Snowden's actions also had an impact on decisions made by the judicial branch. Until 2013 the courts usually applied the state secrets privilege in lawsuits filed by US citizens who believed that government surveillance violated their constitutional rights. Both the Bush and Obama administrations defended the challenged programs, referring to the necessity to protect national security surveillance, and the courts repeatedly declared the lack of standing of the challengers. Even in 2013 such verdicts were announced by the Supreme Court, where the claims were defined as based on "speculation and on a predicted chain of events that might never occur" (Clapper v. Amnesty International 2013). However, Snowden's revelation of the scope and character of the NSA's surveillance legitimized the lawsuits filed by individuals and civil liberties organizations challenging the constitutionality of national security surveillance. In late 2013, the American Civil Liberties Union (ACLU) challenged the NSA's program of bulk collection of phone metadata in the US District Court for the Southern District of New York. The court ruled for the government, finding no violation of the rights of citizens who lacked a reasonable expectation of privacy while providing information to telecommunications companies. However, the appeal of the ACLU to the US Court of Appeals for 
the Second Circuit proved successful, leading to a decision on the illegal status of the bulk telephone metadata program, as a violation of Section 215 of the Patriot Act (ACLU v. Clapper 2013).

A similar decision was made by the US District Court for the District of Columbia in December 2013, when judge Richard J. Leon called the NSA program an indiscriminate and arbitrary invasion of the privacy rights protected by the Fourth Amendment (Klayman v. Obama 2013). Such an inconsistency as that between Klayman and Clapper proves the existence of conflicting approaches in the judicial branch toward national security surveillance. Both decisions ignited the discussion in Congress about the future of the bulk collection of phone data, which resulted in the termination of the program by the provisions of the Freedom Act (Edgar 2017, 4). Judicial control over the legality of national security surveillance affected the legislative process, but it would be too far reaching a conclusion to say that the legislative and judicial branches became united against the secret surveillance system imposed by the executive, as the Court of Appeals' decision was the only serious limitation of national security surveillance in the postSnowden era.

There is no surprise that the next president, Donald Trump, became a strong supporter of national security surveillance. In 2015, during the debate concerning the future of bulk collection of phone metadata, he expressed his support for the program (Council on Foreign Relations 2015). But when he became the subject of a secret FBI investigation about possible connections between his campaign and Russian intelligence, Trump accused the Obama administration of illegal surveillance. Time showed that Trump's negative attitude toward the leaders of intelligence and law enforcement agencies determined his personal decisions as president (Hayden 2018, 139-41). Trump's critical attitude toward the FBI, CIA, and NSA led to a decrease in trust among Republican voters toward the national security agencies, in contrast to some Democratic voters (Nelson 2018, 181). From an institutional perspective, the beginning of Trump's presidency marked a politicization of national security surveillance, the source of which was the personal opinion of the President as an alleged subject of illegal wiretapping.

On the other hand, at the beginning of the second year of Trump's tenure Congress passed the reauthorization of Section 702 of FISA. The legislation was preceded by a few months of public debate concerning the effectiveness of the transparency system under the existing regulations. Despite concerns of the Democrats that the intelligence community would be endangered by the President's influence on surveillance programs, the law was presented as a safeguard for civil liberties and an assurance of greater transparency (Goldsmith and Hennessey 2018). Due to the lack of a serious national security surveillance scandal, the proponents of the new transparency system argued, as in 2007 and 2012, that it worked properly thanks to the broad oversight system imposed by the legislation. One should remember, however, that 
the two earlier reauthorizations of the law had raised hopes for a diminishing of the level of secrecy of national security surveillance, which did not actually happen.

\section{A culture of interbranch secrecy?}

Secrecy had always played an important role in the American political system from the time of its establishment, becoming a valuable tool during the Revolutionary War, when it assured the effectiveness of the government (Ginsberg 2016, 7), and during the Philadelphia Convention, when the Framers referred to the executive branch as the one possessing "the powers of secrecy, vigor, and dispatch" (Farrand 1966, 70). Thus the executive invoked the principle of secrecy as a guarantee of its proper functioning (Graham 2017). The growing impact of secrecy on the operations of the US government in the twentieth century led to the notion that there is a specific culture of secrecy (Moynihan 1997; Theoharis 1998), manifested not only in the amount of classified information kept far away from the public's reach, butabove all - in the conviction that secrecy ensures effectiveness and accountability (Edgar 2017, 345; Ginsberg 2016, 7).

In the twenty-first century the US government agreed to conduct a similar politics of surveillance, supporting the necessary secrecy of government activities relating to security issues, especially when they were undertaken by the executive branch (Laidler 2019). The culture of secrecy is obviously rooted in activities undertaken by presidential administrations, or is a "product of the executive branch's very nature" (Kitrosser 2015, 2). The executive, unlike the legislative and judicial branches, has more space to act in the shadows because both Congress and the courts operate through publicly recorded legislation and written public opinions. Furthermore, the executive branch also has access to human and technological resources, enabling it to act in broader secrecy than any other part of the government (Kitrosser 2015, 2-3).

There is surely a contradictory approach toward the scope of transparency and secrecy between the executive and legislative branches. While presidents have to keep some of their communications and actions secret, Congress's main role is to control these actions either by implementing legislation or imposing oversight measures (Lester 2015, 5). Both branches are involved in a constitutional tug-of-war in the direction of broader secrecy versus more openness. Even the analysis of constitutional provisions concerning the separation of powers as articulated in Article Two leaves the impression that the executive was meant to be the most secret one. All this has led to the creation of various theories supporting the secretive powers of the executive, such as executive privilege, protecting the confidentiality of presidential communications from Congress (Frost 2017; Garvey 2014); unitary executive theory, stemming from the Vesting Clause assigning the president all executive 
powers (Edelson 2016; Calabresi and Yoo 2012); and state secrets privilege, limiting public access to certain national security information (Arnold 2014; Herman 2011).

These theories are obviously in conflict with the traditional understanding of the checks and balances system, as they assume narrow congressional oversight and judicial control of the legality of the national security policies of the executive. In other words, they legitimized certain policies of presidential administrations in the pre- and post-Snowden eras, including the imposition of often unlimited surveillance. The controversy is even greater when one realizes that the government has the discretionary power to decide which information should be kept secret without thoroughly explaining the reasons for its classification as such. However rational it would seem with regard to the intelligence community, which operates within the realm of secrecy ensuring efficacy (Edgar 2017, 76; Sagar 2015, 151), there is no doubt that the executive has overused the paradigm of national security. Furthermore, whenever presidents have announced "times of emergency" it has meant an automatic change in the scope of protection of constitutional rights, such as freedom of speech, freedom of assembly, due process of law, and the right to privacy (Farber 2008; Akerman 2006). Such an approach was usually supported by other branches of government, especially the courts, which followed the rule that in "times of emergency and peril" the scope of the constitutional protection of basic rights and freedoms may be limited (Korematsu v. United States 1944). There is no doubt that extended surveillance measures have played a significant role in the government's use of emergency powers and that national security arguments have enabled the authorities to classify most of their operations in that respect.

Of course, stable and ad hoc congressional committees, inspectors general, courts, and special tribunals have played an important role in imposing control on US surveillance legislation and the executive actions of the national security state (Glennon 2015). Analysis of the character and results of that control proves that, except for the times of increased transparency stemming from press publications or leaks of information concerning surveillance programs (Keller 2017), there has been no clear indication from the controlling institutions about the possible unlawfulness of these programs. Transparency has usually resulted from ex post rather than ex ante congressional oversight (Lester 2015), which proves that the system governing national security surveillance is more likely to promote secrecy than openness. The debates in Congress on the reauthorization or modification of surveillance legislation have ended, in most cases, by reaffirming or even expanding the powers of executive agencies. The only significant changes in preventing the further growth of surveillance powers of the government occurred in times of leaks about secret surveillance programs, such as in the 1970s, and after 2005 and 2013. These were the only moments in which the investigative and oversight 
powers of Congress proved effective, but the analysis of the legislative and institutional outcomes of the postcrisis reforms did not diminish the level of secrecy of national security surveillance.

Similarly, the Supreme Court has never ruled against secret surveillance conducted by the government, and neither has it limited the agencies' surveillance powers (Fisher 2017). Furthermore, the Court has never found any major national security legislation unconstitutional, especially if it adjudicated in times of emergency (Laidler 2011; Akerman 2006). Despite public criticism of certain sections of the Patriot Act by civil rights advocates (Romero and Temple-Raston 2007), the Justices did not address the issue of the constitutionality of these provisions, leaving their modification to Congress in a politically driven legislative process. Lower federal courts were more active in imposing judicial review of the surveillance programs, but when it comes down to the constitutionality of these programs the result is vague. The lack of a transparent and unified position of the federal judiciary on the scope of government surveillance programs strengthens the argument that these programs are legal.

Historically, the courts have hesitated to check the constitutionality of the actions undertaken by the executive, especially when the powers of intelligence agencies, or foreign policy in general, were at stake (Fisher 2017). That leads to another observation, that the federal judiciary was constructed to serve mainly as a "national policy-maker" (Dahl 1957), thus supporting not only the direction of government policies but legitimizing concrete government decisions and programs, provided they protected national security. Even if one argues that such an approach was typical for the early stages of the Cold War, the announcement of the "war on terror" by the Bush administration created an emergency state with national security arguments closing the door to any debate on the constitutionality of secret surveillance programs (Akerman 2006). The problem clearly lies in the culture of secrecy, which may be especially observed with respect to the FISC procedures. If a judge is forced to make a decision concerning the government's request to impose surveillance measures without having access to the full information about the program or to the probable cause of the national security danger caused by the surveilled subject, it is impossible to obtain transparency. Secrecy forces the judicial branch to trust the government in determining the legality of its operations, which can be directly observed in the FISC decisions. According to existing reports, between 1979 and 2009 it approved more than $99 \%$ of government requests for surveillance from 28,000 applications overall (Herman 2011, 112).

The abovementioned examples prove that the principle of separation of powers has been affected by the secrecy of executive actions relating to national security and that both Congress and the courts have agreed to play the game with the rules set out by presidential administrations. 


\section{The illusion of transparency}

The post-Snowden checks and balances system consists of the oversight of national security surveillance by the judges of the FISC and by members of Congress participating in the works of House and Senate intelligence oversight committees, as well as the members of PCLOB, seeking to ensure that surveillance programs do not violate the constitutional rights of Americans. From the structural perspective, each branch is represented in the system, checking whether the institutions responsible for conducting national security surveillance are acting in accordance with the constitution. The legislative branch has the power to reauthorize national security legislation or to adopt new regulations potentially limiting excessive surveillance measures. Congress also has control over the annual budget appropriation, which enables the operation of surveillance programs, and is thus able to determine the character of national security surveillance. At the same time, the federal judiciary has the potential to adjudicate in cases concerning the right of individuals by imposing statutory or constitutional interpretations of government surveillance policies and programs. The power of the courts is not limited to solving disputes stemming from excessive surveillance measures imposed by executive agencies but often comes down to a determination of the parties' legal standing. Additionally, the subjects conducting surveillance, such as the NSA, release several reports regarding the scope of their surveillance programs, thereby becoming the most transparent intelligence community in US history. At least in theory, the current oversight system of national security surveillance should satisfy anyone concerned with the lack of transparency.

In practice, however, when one compares the post-Snowden system with the oversight measures established in the 1970s as a consequence of the Church and Pike Committees' reports, there are no serious institutional differences. The House and Senate intelligence oversight committees have been monitoring national security surveillance since the late 1970s. The level of knowledge of committee members of how the national security surveillance system works may seem higher than 50 years ago, but real changes in that system resulted from uncontrolled leaks to the press rather than effective oversight conducted by these committees (Arnold 2014). Similarly, the lack of serious budget cuts to national surveillance programs (Goldfarb 2015) reveals the congressional attitude toward national security surveillance, not to mention the dramatic change in the character and amount of data intercepted by the government due to broad programs of electronic surveillance. The scope of national security surveillance has changed, but the oversight system does not keep up with these changes.

Congress, as the national legislative body, has always used its power to implement certain regulations aimed at conducting effective control over national security issues. None of the legislation was immune from executive action, which resulted in further expansion of surveillance powers, often 
leading to limitations on the rights of individuals as the price for increased security. On the other hand, despite very active use of judicial review, the Supreme Court rarely entered into the world of national security politics, leaving it to presidential discretion and interpretation. Finally, the special court approving foreign surveillance requests did not play its role effectively for procedural reasons and because of the excessive secrecy around national security surveillance. Secrecy is, therefore, a natural element of foreign surveillance, but it is also the main obstacle to conducting proper oversight of government surveillance. Excessive secrecy means that the system lacks transparent control over executive actions or that the applied measures of control are ineffective and inefficient. In both perspectives, stable or ad hoc control is imposed marginally, as the information shared by the executive about the scope and character of the surveillance programs is limited by the principle of secrecy.

As David Lyon $(1994,24)$ observes, "surveillance is an institutionally central and pervasive feature of social life. Paradoxically, it expanded with democracy." The expansion of national security surveillance became one of the key elements in the evolution of the checks and balances system in American democracy. That evolution was possible not only due to the role of the executive but because Congress and the judicial branch were reluctant to limit presidential attempts to establish a secret national security state. Functioning in an almost never-ending state of emergency enabled those governing to legitimize the implementation of secret NSA programs aimed not only at foreign terrorist suspects but also at American citizens who often did not pose any threat to national security. These programs were and still are defended for their effectiveness, which may be legitimized only because the national security policies are generally kept secret. Whether the purpose of such surveillance measures is always achieved seems disputable, but as long as the system protects the government in the process of limiting the constitutional rights of Americans there is no way to change it, considering that in the contemporary United States, at least in the area of national security surveillance, the meaning of the constitution is determined by all three branches of government.

It seems obvious, then, that secrecy and transparency cannot fully coexist at the same time; therefore, the institutions responsible for interpretation of the law should pose a concrete limit to both values. Such a limit may depend on the state of mind of the society: in times of intensified press investigations, whistleblower leaks, active operation of oversight committees, and frequent judicial review, there is pressure for greater transparency. But in times of crisis, wars, or terrorist attacks, secrecy not only prevails but is treated as a value by both the authorities and the society (Fung et al. 2008, 106). Post-9/ 11 polls indicated that a lot of citizens were ready to give away their freedoms for stronger security and approved of the antiterrorist measures imposed by the government (Davis and Silver 2003; Parenti 2003, 184; Solove 2011, 67). 
In contrast, just after Snowden, when civil liberties were threatened by excessive government surveillance, distrust of the authorities expanded, with four out of five citizens negatively evaluating secret surveillance programs (Epstein 2017, 303).

Analysis of pre- and post-Snowden national security surveillance leads to the impression that the demanded transparency has never been and will never be achieved, and the main reason for this is the way the separation of powers and checks and balances systems work. Although there is no reference in constitutional documents to either secrecy or transparency, the analysis of early writings by the Framers proves that they valued the necessity of imposing a system of government transparency (Arnold 2014, 31), but, at the same time, they accepted a certain level of secrecy, especially of the executive (Frost $2017,146)$. The evolution of the national security state proved, however, that if the government wanted to conduct successful foreign and security policy, it had to keep information about surveillance programs out of public reach. Furthermore, the government was able to select the means by which it would act internationally and domestically; therefore, it was just a matter of time until most of the surveillance measures would be cloaked in total secrecy. The adoption of several theories to legitimize and justify application of these measures was the last step on the way to establishing a secret surveillance state. Today, even if presidents are critical about the level of secrecy of surveillance programs, they prefer to legalize them, rather than withdraw from them (Olmsted 2018). Moreover, according to recent public opinion polls, such an approach is accepted by the majority of society, which wants to feel safe and secure, listing dealing with the terrorism threat as one of the three top public priorities (Pew Research Center 2019).

The rhetoric of safety or security has often served as the legitimization of surveillance policies, and political leaders in democratic states have strongly supported the vision that full security can only be achieved with surveillance measures (Green and Zurawski 2015). In times of internal or external danger, usually referred to as times of emergency, governments have implemented broad surveillance programs that expanded their authority, thus potentially limiting the rights and freedoms of the people (Greenwald 2014; Farber 2008; Akerman 2006). This does not mean that the authorities put aside the discussion of transparency, which could be observed in their rhetoric, and even in some institutional solutions (Fisher 2017, 280). Still, with regard to the national security state, the successful implementation of surveillance measures outweighed the possibility of providing information about their scope and character. In that perspective, the rhetoric of the executive, as well as the establishment of a more transparent oversight system, created an illusion that excessive secrecy has diminished. This means that all of the transparency policies implemented by US government as a result of the Snowden affair-annual transparency reports, internal civil liberties 
monitoring, or the new rhetoric of openness - are just tools with which to convince society that the culture of secrecy has given place to transparency. In reality, however, little has changed: national surveillance is conducted in secret, both with regard to foreign intelligence collaboration and domestic surveillance of potential terrorist suspects. The separation of powers, which is an effective means of control among the branches in several constitutional areas, is not effective with regard to national security. The powers of the executive, rooted in the principle of secrecy, limit congressional and judicial checks and provide no balance; therefore, the illusion of transparency stems mainly from institutional rather than ideological or partisan factors. This all leads to a strengthening of the idea of the national surveillance state, which can be seen as a permanent feature of governance now substituting for the classical national security state (Balkin 2008, 4). If the national surveillance state becomes more powerful, the erosion of the system of checks and balances will continue, further deepening the illusion that Congress and the courts are controlling what the executive does in secret.

\section{References}

ACLU v. Clapper, 959 F.Supp.2d 724 (2013); $14-42$ 2d.Cir (2015).

Akerman, Bruce. 2006. Before the Next Attack: Preserving Civil Liberties in an Age of Terrorism. New Haven: Yale University Press.

Alloa, Emmanuel, and Dieter Thoma. 2018. Transparency, Society, and Subjectivity: Critical Perspectives. New York: Palgrave Macmillan.

Angwin, Julia. 2014. Dragnet Nation: A Quest for Privacy, Security, and Freedom in a World of Relentless Surveillance. New York: Henry Holt and Company.

Arnold, Jason Ross. 2014. Secrecy in the Sunshine Era: The Promise and Failures of US Open Government Laws. Lawrence: University Press of Kansas.

Balkin, Jack M. 2008. "The Constitution in the National Surveillance State." Minnesota Law Review 93(1): 1-25.

Ball, Kirstie, Kevin D. Haggerty, and David Lyon. 2012. The Routledge Handbook of Surveillance Studies. New York: Routledge.

Cain, Bruce E. 2015. Democracy More or Less: America's Political Reform Quandary. New York: Cambridge University Press.

Calabresi, Steven G., and John R. Yoo. 2012. The Unitary Executive: Presidential Power from Washington to Bush. New Haven: Yale University Press.

Church Committee Report. 1976. Final Report of the Select Committee to Study Governmental Operations with Respect to Intelligence Activities, United States Senate, Foreign and Military Intelligence. Washington, DC: GPO.

Clapper v. Amnesty International, 568 U.S. US 398 (2013).

Cole, David, Federico Fabbrini, and Steven Schulhofer. 2017. Surveillance, Privacy, and Transatlantic Relations. New York: Hart Publishing.

Council on Foreign Relations. 2015. Donald Trump on National Security, www.cfr.org.

Dahl, Robert. 1957. "Decision-Making in a Democracy: The Supreme Court as a National Policy-Maker.” Journal of Public 6: 279-95. 
Davis, Darren W., and Brian D. Silver. 2003. "Civil Liberties v. Security: Public Opinion in the Context of the Terrorist Attacks on America." American Journal of Political Science 48(1): 28-46.

Dennis v. United States, 341 U.S. US 494 (1951).

Dudziak, Mary L. 2000. Cold War Civil Rights: Race and Image of American Democracy. Princeton: Princeton University Press.

Edelson, Chris. 2016. Power Without Constraint: The Post-9/11 Presidency and National Security. Madison: The University of Wisconsin Press.

Edgar, Timothy H. 2017. Beyond Snowden, Privacy, Mass Surveillance, and the Struggle to Reform the NSA. Washington, DC: Brookings Institution Press.

Epstein, Edward Jay. 2017. How America Lost Its Secrets: Edward Snowden, the Man and the Theft. New York: Alfred A. Knopf.

Eskens, Sarah, Ot van Daalen, and Nico van Eijk. 2015. Ten Standards for Oversight and Transparency of National Intelligence Services. Institute for Information Law, www.ivir.n1/publicaties/download/1591.pdf.

Farber, Daniel, ed. 2008. Security v. Liberty: Conflicts Between Civil Liberties and National Security in American History. New York: Russell Sage Foundation.

Farrand, Max, ed. 1966. Records of the Federal Convention of 1787. Vol. I. New Haven: Yale University Press.

Farrell, Henry, and Abraham Newman. 2019. Of Privacy and Power: The Transatlantic Struggle over Freedom and Security. Princeton: Princeton University Press.

FISA Amendments Act, 122 Stat. 2436 (2008).

Fisher, Louis. 2013. Presidential War Power. Lawrence: University Press of Kansas.

Fisher, Louis. 2017. Supreme Court Expansion of Presidential Power: Unconstitutional Leanings. Lawrence: University Press of Kansas.

Foreign Intelligence Surveillance Act, 92 Stat. 1783 (1978).

Friedman, Lawrence, and Victor M. Hansen. 2012. "Secrecy, Transparency, and National Security." William Mitchell Law Review 8(5): 1610-28.

Frost, David B. 2017. Classified: A History of Secrecy in the United States Government. Jefferson: McFarland and Company.

Fung, Archon, Mary Graham, and David Weil. 2008. Full Disclosure: The Perils and Promise of Transparency. New York: Cambridge University Press.

Garvey, Todd. 2014. Presidential Claims of Executive Privilege: History, Law, Practice, and Recent Developments. Congressional Research Service, https://fas.org/sgp/crs/ secrecy/R42670.pdf.

Ginsberg, Benjamin. 2016. Presidential Government. New Haven: Yale University Press.

Glennon, Michael J. 2015. National Security and Double Government. New York: Oxford University Press.

Goldfarb, Ronald J. 2015. After Snowden: Privacy, Secrecy, and Security in the Information Age. New York: Thomas Dunne Books.

Goldsmith, Jack, and Susan Hennessey. 2018. "The Merits of Supporting 702 Reauthorization(Despite Worries About Trump and the Rule of Law)." Lawfare Blog, January 18, www.lawfareblog.com/merits-supporting-702-reauthorization-despiteworries-about-trump-and-rule-law.

Graham, Mary. 2017. Presidents' Secrets: The Use and Abuse of Hidden Power. New Haven: Yale University Press.

Green, Nicola, and Nils Zurawski. 2015. "Surveillance and Ethnography: Researching Surveillance as Everyday Life.” Surveillance \& Society 13(1): 27-43. 
Greenwald, Glenn. 2014. No Place to Hide: Edward Snowden, the NSA, and the U.S. Surveillance State. New York: Henry Holt.

Gurnow, Michael. 2014. The Edward Snowden Affair: Exposing the Politics and the Media Behind the NSA Scandal. Indianapolis: Blue River Press.

Hayden, Michael V. 2018. The Assault on Intelligence: American National Security in an Age of Lies. New York: Penguin Press.

Herman, Susan N. 2011. Taking Liberties: The War on Terror and the Erosion of American Democracy. New York: Oxford University Press.

Johnson, Loch K. 2018. Spy Watching: Intelligence Accountability in the United States. New York: Oxford University Press.

Keller, William W. 2017. Democracy Betrayed: The Rise of the Surveillance Security State. Berkeley: Counterpoint.

Kitrosser, Heidi. 2015. Reclaiming Accountability: Transparency, Executive Power, and the U.S. Constitution. Chicago: University of Chicago Press.

Klayman v. Obama, 957 F. Supp 2d.1 (2013).

Korematsu v. United States, 323 U.S. US 214 (1944).

Kuntze, Jan-Hendrik. 2018. The Abolishment of the Right to Privacy? The USA, Mass Surveillance and the Spiral Model. Baden-Baden: Tectum Verlag.

Laidler, Paweł. 2011. Sad Najwyzszy Stanow Zjednoczonych Ameryki. Od prawa do polityki. Krakow: Jagiellonian University Press.

Laidler, Paweł. 2019. "How Republicans and Democrats Strengthen Secret Surveillance in the United States." Political Preferences 25: 5-20.

Laird v. Tatum, 408 U.S. US 1 (1972).

Lester, Genevieve. 2015. When Should State Secrets Stay Secret? Accountability, Democratic Governance, and Intelligence. New York: Cambridge University Press.

Lyon, David. 1994. The Electronic Eye. The Rise of Surveillance Society. Minneapolis: University of Minnesota Press.

Lyon, David. 2014. "Surveillance, Snowden, and Big Data: Capacities, Consequences, Critique." Big Data \& Society 1(2): 1-13.

Lyon, David. 2015. Surveillance After Snowden. Cambridge: Polity.

McCabe, Andrew G. 2019. The Threat: How the FBI Protects America in the Age of Terror and Trump. New York: St. Martin's Press.

Moses, Lyria Bennett, and Louis de Koker. 2017. "Open Secrets: Balancing Operational Secrecy and Transparency in the Collection and Use of Data by National Security and Law Enforcement Agencies." Melbourne University Law Review 41(2): $1-41$.

Moynihan, Daniel P. 1997. “The Culture of Secrecy.” Public Interest 128: 55-72.

National Security Act, 61 Stat. 496 (1947).

Nelson, Michael. 2018. Trump: The First Two Years. Charlottesville: University of Virginia Press.

Olmsted, Kathryn. 2018. "Terror Tuesdays: How Obama Refined Bush's Counterterrorism Policies." In The Presidency of Barack Obama: A First Historical Assessment, edited by Julian E. Zelizer. Princeton: Princeton University Press.

Parenti, Christian. 2003. The Soft Cage: Surveillance in America. From Slavery to the War on Terror. New York: Basic Books.

Pew Research Center. 2019. Public's 2019 Priorities: Economy, Health Care, Education and Security All Near Top of List, www.pewresearch.org/politics/2019/01/24/publics2019-priorities-economy-health-care-education-and-security-all-near-top-of-list/. 
Posner, Eric A. and Adrian Vermeule. 2006. Terror in the Balance: Security, Liberty, and the Courts. New York: Oxford University Press.

Prados, Jeff. 2014. The Family Jewels: The CIA, Secrecy, and Presidential Power. Austin: University of Texas Press.

Presidential Policy Directive, 28 January 17, (2014).

Protect America Act, 121 Stat. 552 (2007).

Romero, Anthony D., and Dina Temple-Raston. 2007. In Defense of Our America: The Fight for Civil Liberties in the Age of Terror. New York: William Morrow.

Sagar, Rahul. 2015. "Against Moral Absolutism: Surveillance and Disclosure After Snowden." Ethics and International Affairs 29(2): 145-59.

Smith, Cary Stacy, and Li-Ching Hung. 2010. The Patriot Act: Issues and Controversies. Springfield: Charles C. Thomas.

Solove, Daniel J. 2011. Nothing to Hide: The False Tradeoff Between Privacy and Security. New Haven: Yale University Press.

Theoharis, Athan G. 2011. Abuse of Power: How Cold War Surveillance and Secrecy Policy Shaped the Response to 9/11. Philadelphia: Temple University Press.

Theoharis, Athan G., ed. 1998. A Culture of Secrecy: The Government Versus the People's Right to Know. Lawrence: University of Kansas Press.

United States v. Reynolds, 345 U.S. US 1 (1953).

USA Freedom Act, 129 U.S. US 268 (2015).

USA Patriot Act, 115 Stat. 272 (2001).

USA Patriot Act Additional Reauthorizing Amendments, 120 Stat. 278 (2006).

Van Dijck, Jose. 2014. "Datafication, Dataism and Dataveillance: Big Data Between Scientific Paradigm and Ideology." Surveillance \& Society 12(2): 197-208. 